\title{
History and Diversity of Citrus leprosis virus Recorded in Herbarium Specimens
}

\author{
John S. Hartung, Avijit Roy, Shimin Fu, Jonathan Shao, William L. Schneider, and Ronald H. Brlansky
}

First and fourth authors: United States Department of Agriculture-Agricultural Research Service (USDA-ARS) Molecular Plant Pathology Laboratory, Beltsville, MD 20705; second and fifth authors: USDA-ARS Foreign Diseases and Weed Sciences Research Unit, Fort Detrick, MD; third author: USDA-ARS Molecular Plant Pathology Laboratory and Southwest University, Citrus Research Institute, Chongqing, China 400715; and sixth author: University of Florida, Citrus Research and Education Center, Lake Alfred 33850.

Accepted for publication 27 April 2015.

\begin{abstract}
Hartung, J. S., Roy, A., Fu, S., Shao, J., Schneider, W. L., and Brlansky, R. H. 2015. History and diversity of Citrus leprosis virus recorded in herbarium specimens. Phytopathology 105:1277-1284.

Leprosis refers to two diseases of citrus that present similar necrotic local lesions, often surrounded by chlorotic haloes on citrus. Two distinct viruses are associated with this disease, one that produces particles primarily in the nucleus of infected plant cells (Citrus leprosis virus nuclear type [CiLV-N]; Dichorhavirus) and another type that produces particles in the cytoplasm of infected plant cells (Citrus leprosis virus cytoplasmic type [CiLV-C]; Cilevirus). Both forms are transmitted by Brevipalpid mites and have bipartite, single-stranded, RNA genomes. CiLV-C and CiLV-N are

present in South and Central America and as far north as parts of Mexico. Although leprosis disease was originally described from Florida, it disappeared from there in the 1960s. The United States Department of AgricultureAgricultural Research Service maintains preserved citrus specimens identified at inspection stations 50 or more years ago with symptoms of citrus leprosis. We isolated RNA from these samples and performed degradome sequencing. We obtained nearly full-length genome sequences of both a typical CiLV-C isolate intercepted from Argentina in 1967 and a distinct CiLV-N isolate obtained in Florida in 1948. The latter is a novel form of CiLV-N, not known to exist anywhere in the world today. We have also documented the previously unreported presence of CiLV-N in Mexico in the mid-20th century.
\end{abstract}

The first reports of what is known today as citrus leprosis were from Florida, in the United States, more than 100 years ago, when the disease was referred to as scaly bark due to a typical symptom of coalesced local lesions on green bark (Fawcett 1911). A disease with similar symptoms was simultaneously observed in South America and also came to be referred to as citrus leprosis (Bastianel et al. 2010). Trees with citrus leprosis have necrotic lesions, often with yellow haloes, on the leaves, bark, and fruit (Bastianel et al. 2010; Castillo et al. 2011; Roy et al. 2013a). The circular lesions can overlap and kill a shoot by girdling, and the disease can also cause yield loss due to fruit and leaf drop. Sweet orange is the variety of citrus most susceptible to leprosis, although symptoms may also be seen on mandarin types (Bastianel et al. 2008) as well as on lemon (Roy et al. 2015), lime, sour orange, and grapefruit, which are considered, however, to be relatively resistant to the disease. It has been possible to exploit this resistance in breeding programs to develop more tolerant varieties of citrus (Bastianel et al. 2006).

The cause of citrus leprosis was difficult to establish, and various fungi were proposed as the causal agent in both Florida and South America in early research. The disease was shown to be associated with feeding by Tenuipalpid mites, and transmission of the etiological agents by mites in the genus Brevipalpus has been confirmed more recently (Rodrigues et al. 2003). Because of this, the lack of fungi consistently associated with the disease, and the ring spot symptoms, which resembled symptoms caused by other

Corresponding author: J. S. Hartung; E-mail address: john.hartung@ars.usda.gov

*The $\boldsymbol{e}$-Xtra logo stands for "electronic extra" and indicates that one supplementary figure and two supplementary tables are published online.

http://dx.doi.org/10.1094/PHYTO-03-15-0064-R

This article is in the public domain and not copyrightable. It may be freely reprinted with customary crediting of the source. The American Phytopathological Society, 2015. known plant viruses, a viral etiology for the disease was proposed (Bitancourt 1955). When attempts were made to transmit the presumed virus by grafting of infected scions on rootstocks, symptoms did not become systemic in the receptor plants. However, Knorr (1968) and, later, others (Chagas and Rosetti 1984), showed that local lesions would expand into healthy receptor tissue if bud sticks were cut so that lesions were placed in direct contact with healthy tissue. The case for viral etiology of the disease was further strengthened by the description of bacilliform viral particles in the nucleus of cells in leprosis lesions (Kitajima et al. 1972). Similar but shorter particles were observed later in viroplasm in the cytoplasm of infected tissues in other specimens (Colariccio et al. 1995). In this same work, lesions similar to those observed in sweet orange with symptoms of leprosis were induced in herbaceous hosts following rub inoculation with macerated leprosis lesions, thus confirming the viral etiology of the disease (Colariccio et al. 1995).

It became clear that citrus leprosis is the name given to two different diseases, each with similar symptoms in citrus and Brevipalpid mites as vectors, but with different viral agents. The virus found primarily in the nuclei of infected cells, Citrus leprosis virus nuclear type (CiLV-N), is a member of the proposed genus Dichorhavirus (Dietzgen et al. 2014), and is closely related to Orchidfleck virus (OFV) (Kondo et al. 2003, 2006; Roy et al. 2013c). CiLV-N has a bipartite, negative-sense, and single-strand RNA genome. Genomic RNA 1 of isolate M2345 is 6,269 nucleotides (nt) in length and encodes a nucleocapsid protein and a glycoprotein as well as three hypothetical proteins (Roy et al. 2013c). Genomic RNA 2 of isolate M2345 is 5,860 nt in length and encodes the viral polymerase polyprotein (Roy et al. 2013c). Citrus leprosis virus cytoplasmic type (CiLV-C) also has a bipartite and single-stranded RNA genome but is encoded in the positive sense. It is the type member of the genus Cilevirus (Locali-Fabris et al. 2006). Genomic RNA 1 of CiLV-C is 8,745 nt and encodes a large polyprotein and a putative coat protein designated p29. Genomic RNA 2 of CiLV-C 
is $4,986 \mathrm{nt}$ and encodes a movement protein (p32) and proteins designated p15, p24, and p61 (Locali-Fabris et al. 2006). Although electron micrographs of CiLV-N were originally obtained in Brazil (Kitajima et al. 1972), CiLV-N is difficult to find there today, although closely related viruses are found in ornamentals (Kitajima et al. 2003). However, CiLV-C is widespread in Brazil, and has been spreading steadily in South America, and has now been reported in Central America (de Dominguez et al. 2001; Rodrigues et al. 2006) and, more recently, in southern Mexico (Castillo et al. 2011) and, thus, poses an immediate threat to the sweet orange industries in Florida and California in particular, and also to the grapefruit industry of Texas (Childers et al. 2003).

The history of CiLV in Florida is very unusual. CiLV was originally described in Florida in 1911, as mentioned above, and was for many years a very important disease problem for the Florida citrus industry. Then, in the mid 1960s, the disease disappeared from Florida and has not been reported there since. The disappearance of the disease was associated with the effective use of wetable sulfur chemistries in acaricides and a severe freeze in 1962, which killed large areas of groves in the citrus-producing regions. When citrus was replanted, in areas generally south of the previous groves, citrus leprosis was no longer present, and had been apparently eradicated (Childers et al. 2001). Thus, the original CiLV from Florida has not been available for study.

Botanical specimens are deposited into herbaria and dried and stored in order to provide voucher specimens in support of valid nomenclature. Specimens have also been placed into herbaria to document outbreaks of plant diseases. For example, specimens of potato leaves with symptoms of late blight disease, caused by Phytophthora infestans, were deposited in herbaria in the 19th century. The advent of polymerase chain reaction (PCR) methods made it possible to use these specimens to identify the genotype of $P$. infestans associated with the Irish potato famine, which is no longer extant (Ristaino 1998; Ristaino et al. 2001). These and other specimens have been used to document the evolution of genotypes of $P$. infestans over the past two centuries in response to the efforts of plant breeders to control the disease (Yoshida et al. 2014). Specimens of citrus leaves were preserved in the herbarium of the United States National Fungus Collection (USNFC) at Beltsville, MD to document citrus canker disease (Stall and Civerolo 1993), and were used to trace the historical path of distribution of Xanthomonas citri around the world, principally through Japan (Li et al. 2007).

Specimens of citrus with symptoms identified as citrus leprosis have also been preserved in the USNFC herbarium. These specimens are typically sweet orange peels with lesions typical for leprosis but also include a few specimens of leaves and stems. These specimens were deposited in the herbarium from 1932 to 1967 by workers at United States Department of Agriculture (USDA) inspection stations who intercepted sweet orange samples that had originated throughout South and Central America. Samples were also deposited of leprosis-affected citrus collected in Florida.

Previously, we used next-generation RNA sequencing methods to determine the genomic sequence of a novel species of Cilevirus, CiLV-C2 from Colombia (Roy et al. 2013a) and to determine the genome sequence of isolates of CiLV-N from Mexico (Roy et al. 2013c). We have now applied RNA sequencing methods to samples identified as CiLV from the herbarium of the USNFC. We have been able to assemble nearly complete genome sequence data for both a typical CiLV-C type virus from Argentina preserved in 1967 and a novel form of CiLV-N preserved from Florida in 1948. We also have recovered sequence data that is less extensive but sufficient for species identification from other samples in the collection.

\section{MATERIALS AND METHODS}

Herbarium specimens. The citrus specimens that were used in this study were deposited in the herbarium due to putative infection with citrus leprosis but were not part of the annotated collection of the USNFC herbarium. The specimens were recorded as collected from either sweet orange (Citrus sinensis) or bitter or sour orange (C. aurantium) (Table 1). The specimens were intercepted at various points of entry to the United States from 1932 to 1967 and identified with symptoms of citrus leprosis by eminent authorities of the era. Among these, all but one were preserved as dried fruit peel. One specimen was prepared in Brazil in 1932 and is a formal herbarium specimen that preserves the stems, leaves, and small fruit of sweet orange samples, although the entire specimen is very brown from extensive oxidation. The specimens originated in four countries: the United States (Florida), Brazil (Sao Paulo), Argentina, and Mexico. The peels were more or less uniformly preserved and were very dry and

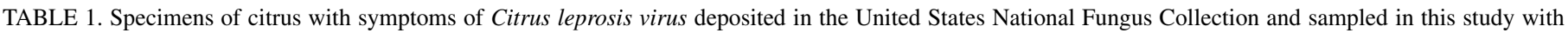
summary statistics of the RNA sequencing runs

\begin{tabular}{|c|c|c|c|c|c|c|}
\hline Sample & Origin & Host & Yield $^{\mathrm{a}}$ & Number of reads & $\mathrm{Q}$ scores $>30(\%)^{\mathrm{b}}$ & Mean $\mathrm{Q}^{\mathrm{b}}$ \\
\hline 5 & Brevard, Florida, 1947 & Citrus sinensis & 2,538 & $49,756,290$ & 90.5 & 35.75 \\
\hline 6 & Volusia, Florida, 1948 & C. sinensis & 2,963 & $58,103,150$ & 93.7 & 36.96 \\
\hline 12 & Mexico, 1955 & C. aurantium & 3,342 & $65,528,363$ & 93.56 & 36.91 \\
\hline 13 & Argentina, 1949 & C. aurantium & 3,010 & $59,027,095$ & 93.96 & 37.05 \\
\hline 20 & Argentina, 1967 & C. sinensis & 2,637 & $51,715,545$ & 91.18 & 36.02 \\
\hline 22 & Mexico, 1967 & C. sinensis & 3,596 & $70,513,388$ & 90.95 & 35.91 \\
\hline 34 & Sao Paulo, Brazil, 1932 & C. sinensis & 3,090 & $60,597,953$ & 93.88 & 37.05 \\
\hline
\end{tabular}

a Million bases.

b Phred quality score. Q30 means that the probability of a correct base call is $99.9 \%$.
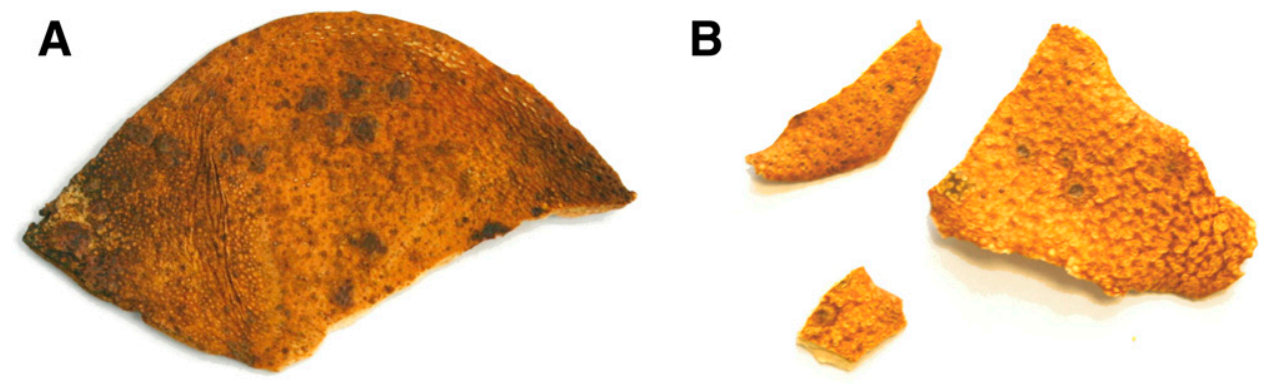

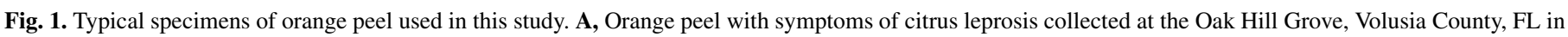

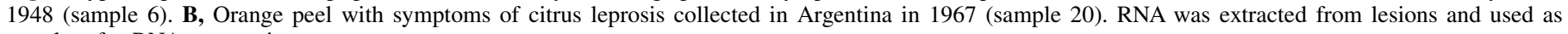
template for RNA sequencing. 
brittle. Symptoms that are consistent with both CiLV-C from Argentina and CiLV-N from Florida can be seen in the specimens (Fig. 1).

Extraction of RNA and sequencing of small RNA. Small samples of orange peel, typically containing three or fewer localized lesions, were broken off from the fruit peels. Disposable gloves and other precautions were used to protect the samples and to prevent cross contamination. Samples were flash frozen in liquid nitrogen and ground to powder in mortars with pestles that had been baked at $300^{\circ} \mathrm{C}$ for 2 days. The powder was transferred to 1.5-ml centrifuge tubes. Total RNA was extracted with Trizol (Invitrogen) and treated with Turbo DNase (Ambion) according to the manufacturers' instructions. Following the DNase treatment, the RNA was extracted with phenol/chloroform/isoamyl alcohol (25:24:1), chloroform/isoamyl alcohol (24:1), and then precipitated with isopropanol overnight. Finally, the RNA was washed with $75 \%$ ethanol two times and suspended in RNA Secure (Ambion Life Technologies). The quantity of total RNA was determined with a Qubit 2.0 Fluorometer (Invitrogen) and RNA quality was assessed using the Bioanalyzer 2100 (Agilent Technologies). RNA was sent to a commercial partner (Genewiz), and small RNA (sRNA) libraries were prepared, the samples were multiplexed, and $1 \times 50$ HiSeq (Illumina) RNA sequencing was carried out.

Bioinformatic processing of sequence data. Sequence data were obtained and libraries of reads in fastq format ranging from 15 to 35 bases containing potential virus sequences were identified through a subtractive approach (Roy et al. 2013b). Sequences from the citrus genome (Xu et al. 2012) were identified and removed using short-read alignment tools bowtie version 0.12.7 (Langmead et al. 2009) and STAR version 2.3.0. The remaining reads were assembled using the Velvet/Oases suite using various k-mers (Schulz et al. 2012; Zerbino and Birney 2008). The resulting transcripts and contigs and, in select cases, reads were subjected to a blastX search (Altschul et al. 1997) against the nonredundant protein database from the National Center for Biotechnology Information (NCBI) (http://www.ncbi.nlm.nih.gov/) using the default parameters. Reads were also mapped directly to known viruses and used as blast $\mathrm{X}$ and blastN query sequences of custom virus databases containing CiLV, OFV, Citrus necrotic spot virus (CiNSV), and Coffee ring spot virus (CoRSV). Sequences that matched virus sequences with low $e$ values were identified and compiled.

Phylogenetic relationships among CiLV-N isolates. RNA sequence data from the nucleocapsid genes of isolate M2345 of CiLV-N, isolate Jal1 of CiNSV, the So and NHSS1 isolates of OFV, an isolate of CoRSV, and nucleo- and cytorhabdovirus sequences obtained from GenBank were included in this study. Apart from these sequences, an $N$ gene sequence of CiLV-N2, a novel type of CiLV-N that we have described recently from Mexico (Roy et al. 2014), and the sequence of the $N$ gene from our Florida herbarium sample number 6 also were included. The sequence data were aligned with the CLUSTAL-X program (Thompson et al. 1997) and further analyzed using GeneDoc (Nicholas and Nicholas 1997). Phylograms that summarized the relationships among the sequences were calculated using neighbor joining with MEGA-6 (Tamura et al. 2013) and Treeview 2.

\section{RESULTS}

Specimen quality, RNA extraction and sRNA sequencing. The specimens of orange peel were dry and brittle but otherwise well preserved. Similar necrotic lesions were present on sample 6 from Florida in 1948 and sample 20 from Argentina in 1967 (Fig. 1). Seven specimens were selected for this study, and the RNA extraction from one of them, from Brazil, was repeated. The estimated initial quantity of RNA obtained after the Trizol extraction from the preserved lesions was comparable with that obtained from a similar amount of fresh sweet orange peel (not shown). As might be expected, the quality of the RNA obtained from these specimens was very poor. As can be seen from the digital electrophoresis gel created by the bioanalyzer software, the sample extracts were generally uniform, with numerous faint bands. No $18 \mathrm{~S}$ or $28 \mathrm{~S}$ ribosomal RNA bands were present in any sample, indicating that massive nonspecific degradation had occurred (Fig. 2A). The RNA Integrity Numbers (RIN), a standard measure of RNA degradation calculated from digital traces of each sample (Schroeder et al. 2006), ranged from 1.6 to 2.4 , and sample 20 did not produce any RIN (Fig. 2B). A RIN of 8.0 or better is considered to be necessary for reliable RNA gene expression studies. In spite of the poor RIN statistic, the RNA did provide a template for $1 \times 50$ RNA sequencing, with an average of approximately 58 million reads and 2,945 MB of sequence data for each sample with similar quality statistics (Table 1).
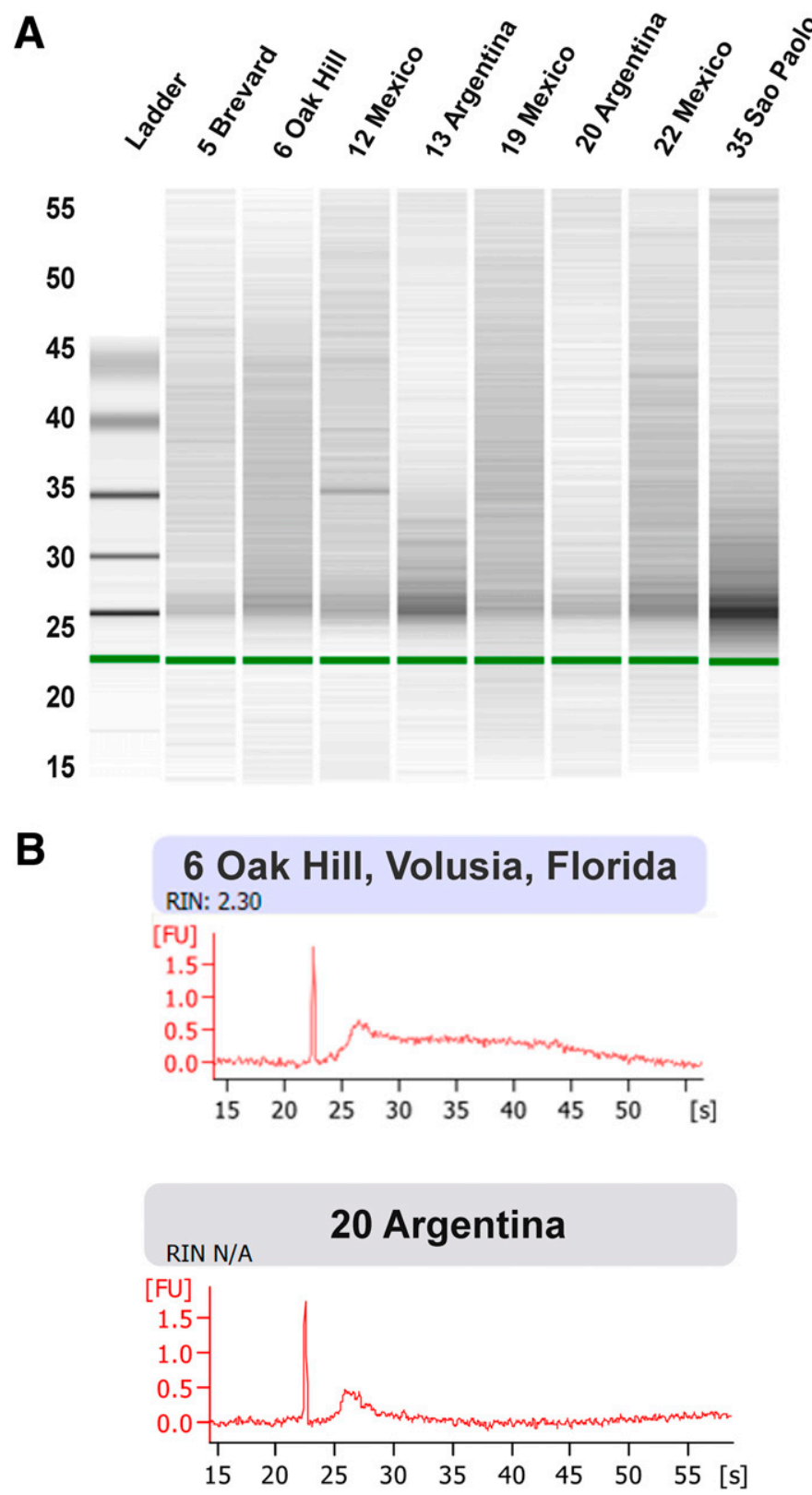

Fig. 2. Characterization of RNA isolated from herbarium samples with the Bioanalyzer prior to RNA sequencing. A, Representation of electrophoresis of RNA samples after extraction from the herbarium samples, calculated in silico from the Bioanalyzer data. The Y axis is time in seconds following injection of the sample and the prominent band at $22 \mathrm{~s}$ is the tracking dye. B, Fluorescence scan of the lanes indicated from gel shown in $\mathrm{A}$. The $\mathrm{Y}$ axis is fluorescence and the $\mathrm{X}$ axis is seconds following injection of the sample. 
Reads were assembled from all of the libraries. The greatest success was with the library for specimen number 20, deposited from Argentina in 1967. Reads from this library were assembled into 67 contigs for genomic RNA 1 and 41 contigs for genomic RNA 2 (Fig. 3; Supplementary Tables S1 and S2). Contigs ranged in size from 65 to $292 \mathrm{nt}$, with an average length of $117 \mathrm{nt}$. The total length of the reads mapped to genomic RNA 1 was 7,787 nt, for a total coverage of approximately $89 \%$ of the $8,730-$ nt genomic RNA 1 reference genome (DQ388512). The total length of the reads mapped to genomic RNA 2 was $4,895 \mathrm{nt}$, for a total coverage of approximately $98 \%$ of the 4,969-nt genomic RNA 2 reference genome (DQ388513). These contigs were generally 99 to $100 \%$ identical to the reference genome of CiLV-C (Locali-Fabris et al. 2006; Pascon et al. 2006) and mapped to the CiLV-C genome with $e$ values that approached or equaled 0 , thus identifying this isolate of $\mathrm{CiLV}$ as a typical isolate of CiLV-C.

An exceptional assembly of contigs was also obtained with specimen number 6, originally deposited by Knorr from Florida in 1948. Reads from this library were assembled into four long contigs that mapped to Dichorhavirus genomic RNA 1 and three long contigs that mapped to Dichorhavirus genomic RNA 2, providing $61 \%$ coverage of the two genomic RNAs (Fig. 4A; Table 2). These contigs provided complete coverage of both the $N$ gene and the glycoprotein gene, as well as a fragment of the coding sequence for the putative movement protein on genomic RNA 1 and substantial coverage of the polyprotein encoded by genomic RNA 2 . Like the sample from Argentina, the sample from Florida had excellent coverage of a reference CiLV genome but, in this case, it was to CiLV-N (Roy et al. 2013c). Coverage of the contigs was typically 98 to $99 \%$ with the reference genome but, in contrast to the sample from Argentina, the identity of the nucleotide sequence was only $80 \%$ when compared with the reference M2345 genomic sequences KF209275 and KF209276 (Roy et al. 2013c). Nonetheless, the $e$ values of the comparison of these contigs with the reference sequences approached or equaled zero (Table 2).

Another excellent assembly of contigs was obtained with sample number 22, obtained from Mexico in 1967. Nearly all of the genomic RNA 2 was assembled from the sequence data but much less of the genomic RNA 1 was assembled from the sequence data (Fig. 4B). The sequences obtained had $e$ values that approached 0 and nucleotide identities approaching $100 \%$ when compared with the CiLV-N reference sequences KF209275 and KF209276, which are from a contemporary specimen of CiLV-N from Mexico (Table 3). Thus, this specimen is closely related genetically to the contemporary isolate M2345.

We were able to obtain only fragmentary sequence data from sample number 12, collected in Mexico in 1955. As was the case with sample 22, we obtained better coverage for genomic RNA 2 (Fig. 4C). We compared the percent identity of the amino acid sequences translated from the contigs obtained for genomic RNA 2 from samples 12 and 22. The amino acid sequences of genomic RNA 2 of sample 22 were $97 \pm 0.5 \%$ identical to those of contemporary strain M2345 but the amino acid sequences obtained from genomic RNA 2 of sample 12 were only $91 \pm 2 \%$ identical to those of contemporary strain M2345. Thus, the two samples represent different lineages of CiLV-N in Mexico.

We were not able to obtain sufficient sequence data from some of the samples to make firm conclusions regarding the identity of the virus present in the sample. Only two contigs that matched CiLV-N-related sequences (2e-13) were found in sample number 13 from Mexico, and only three short contigs were assembled from sample number 5, deposited from Florida. Only three contigs were assembled from sample number 34, deposited from Brazil in 1932. These matched CiLV-C sequences (3e-22).

The complete sequences of the nucleocapsid and glycoprotein genes of the CiLV sample from Florida were used for a phylogenetic comparison with other members of Dichorhavirus and cyto- and nucleorhabdovirus sequences available at NCBI. These phylograms revealed both diversity and relative relationships within the CiLV-N group of isolates. However, the data from the glycoprotein gene (Fig. 5) produced a more robust and phylogenetically informative phylogram than did the data from the nucleocapsid gene (Supplementary Fig. S1). Because the specimen that was used to obtain the sequence data for CiLV from Florida was preserved in 1948, it predates the specimens used to obtain the other sequence data in the CiLV-N group, and we refer to this sequence as CiLV-N0. The nucleocapsid and glycoprotein amino acid sequences of CiLV-N0 had $92 \%$ similarity with CiLV-N and OFV, 93\% with CiNSV, and 94\% with CiLV-N2. In both phylograms, CiLV N0 and CiLV-N2 shared a branch with OFV, and the reference CiLV-N sequence (KF209275 and KF209276) appears to be most closely related to the common ancestor of the Dichorhavirus clade.

Most interestingly, the sample of CiLV preserved from Florida in 1948 appears to be a representative of a distinct group within the Dichorhavirus genus. It is clearly distinct from the contemporary OFV, CiNSV, and CiLV-N and most closely related to the CiLV-N2 strains recently found in Mexico (Roy et al. 2014). Thus, the sample from the herbarium represents a previously unknown lineage of Dichorhavirus, and one that is not known to exist in the world today.

\section{DISCUSSION}

Previous workers have used PCR-based technology to identify pathogens in herbarium specimens (Li et al. 2007; Ristaino et al. 2001; Yoshida et al. 2014). In the case of CiLV, this would have required reverse transcription of RNA followed by PCR amplification, and the age of the herbarium samples and state of degradation of the RNA precluded this relatively simple approach.

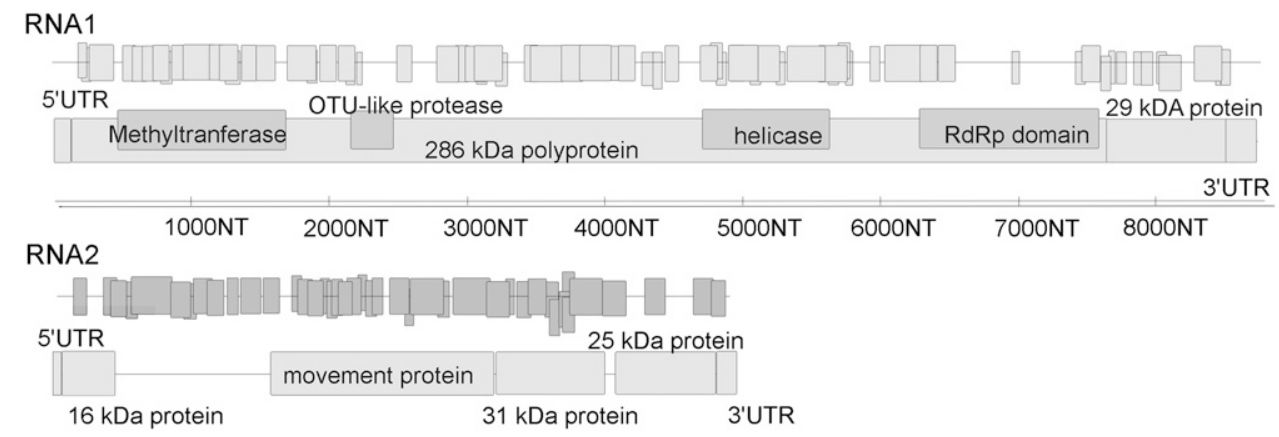

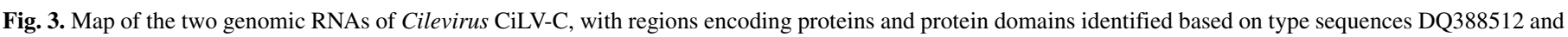

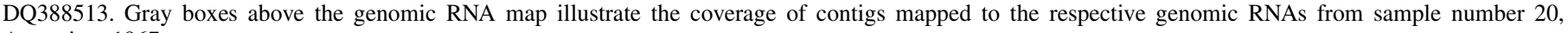
Argentina, 1967. 
Likewise, the closure of gaps remaining in the sequence assemblies by PCR-based methods was also precluded by the state of the RNA. However, the positive-sense RNA genome of the Cilevirus CiLV-C replicates through double-stranded (ds)RNA intermediates (LocaliFabris et al. 2006), and both this dsRNA and the RNA products of gene silencing (Baulcombe 2004; Hamilton et al. 2002) are relatively stable and can be accessed by deep sequencing of the degradome (Loconsole et al. 2012a,b; Roy et al. 2013b,c). Therefore, we purified small RNA fragments from the dried orange peels to use them for Illumina-based sequencing. Note, however, that the negative-sense RNA genome of Dichorhavirus will likely produce much smaller amounts of dsRNA than positive-sense RNA viruses (Weber et al. 2006).

As noted above, symptoms of citrus leprosis are seen on sweet orange foliage, fruit, and stems when either of two unrelated and flat mite-transmitted viruses is present. In our samples, we found representatives of both viruses. Sample number 20, obtained from
TABLE 2. Contigs that were assembled from library of sample number 6 , CiLV-NO, Volusia County, FL, $1948^{\mathrm{a}}$

\begin{tabular}{|c|c|c|c|c|}
\hline Position & Length (nt) ${ }^{\mathrm{b}}$ & Coverage $(\%)$ & $e$ Value ${ }^{c}$ & Identity (\%) \\
\hline \multicolumn{5}{|l|}{ RNA 1} \\
\hline $20-1,007$ & 1,007 & 98 & 0 & 81 \\
\hline $1,570-966$ & 616 & 98 & 9 e-154 & 83 \\
\hline $2,728-3,315$ & 595 & 98 & $1 \mathrm{e}-127$ & 81 \\
\hline $4,614-6,208$ & 1,906 & 91 & 0 & 76 \\
\hline \multicolumn{5}{|l|}{ RNA 2} \\
\hline $823-2,245$ & 1,434 & 99 & 0 & 80 \\
\hline $3,308-2,442$ & 870 & 99 & 0 & 81 \\
\hline $4,245-5,581$ & 1,346 & 99 & 0 & 82 \\
\hline
\end{tabular}

a Position (contigs that mapped to genomic RNA 1 or RNA 2), coverage, and percent identity to corresponding segments of the reference sequences KF209275 and KF209276.

b Length in nucleotides (nt)

${ }^{c}$ Expected value of the Blast match between these contigs and the reference genomic RNAs.

A

RNA1

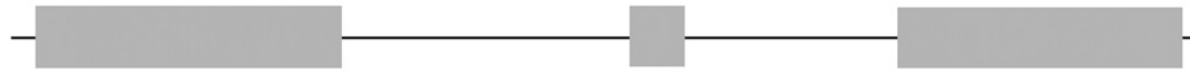

RNA2

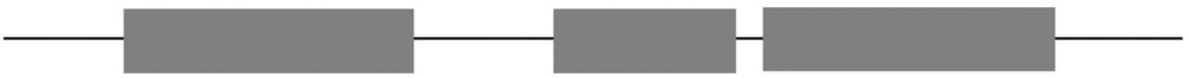

B

RNA1

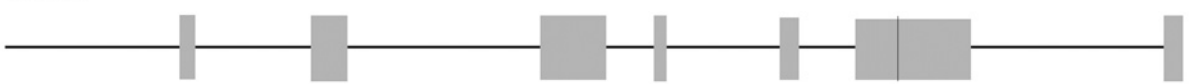

RNA2

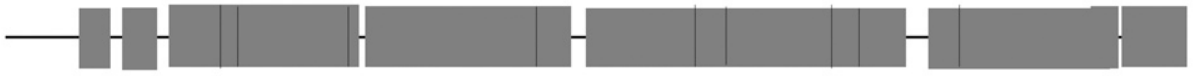

C

RNA1

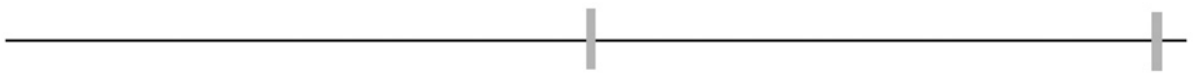

RNA2

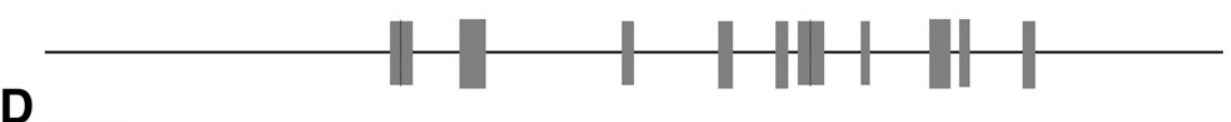

RNA1

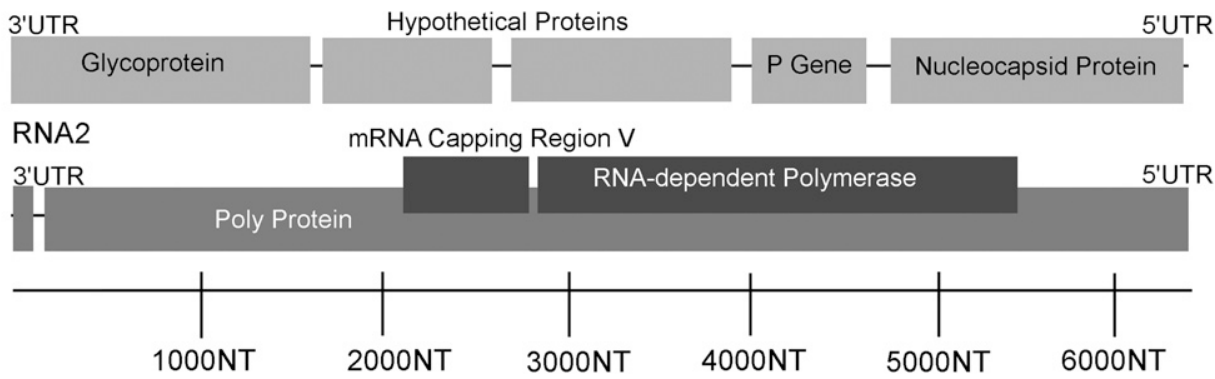

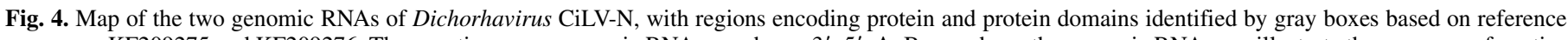

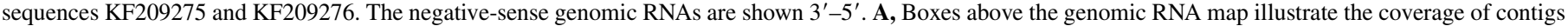

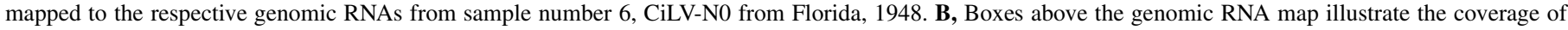

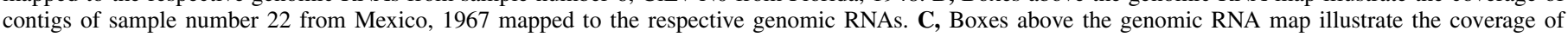

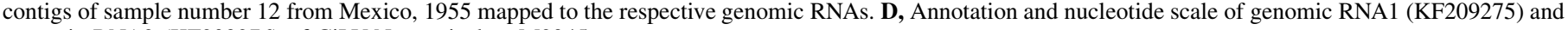
genomic RNA2 (KF209276) of CiLV-N type isolate M2345. 
a source in Argentina in 1967, is an absolutely typical representative of CiLV-C and belongs to the genus Cilevirus. The 108 contigs that mapped to genomic RNA 1 and genomic RNA 2 of CiLV-C averaged $117 \mathrm{nt}$ in length, and most had coverage of $100 \%$ of the reference CiLV-C sequences (DQ388512 and DQ388513) available from GenBank. The nucleotide sequences were typically 99 to

TABLE 3. Contigs that were assembled from library of sample number 22, CiLV-N, Mexico, $1967^{\mathrm{a}}$

\begin{tabular}{lcclc}
\hline Position & Length (nt) $)^{\mathrm{b}}$ & Coverage $(\%)$ & $e$ Value & Identity $(\%)^{\mathrm{c}}$ \\
RNA 1 & & & & \\
$2-76$ & 75 & 100 & $8 \mathrm{e}-09$ & 100 \\
$918-1,340$ & 423 & 100 & $1 \mathrm{e}-92$ & 100 \\
$1,341-1,496$ & 156 & 99 & $5 \mathrm{e}-26$ & 100 \\
$1,724-1,870$ & 147 & 100 & $2 \mathrm{e}-23$ & 96 \\
$2,351-2,431$ & 81 & 98 & $5 \mathrm{e}-08$ & 93 \\
$2,675-2,977$ & 303 & 100 & $3 \mathrm{e}-56$ & 93 \\
$4,346-4,495$ & 150 & 99 & $2 \mathrm{e}-22$ & 94 \\
$5,212-5,292$ & 81 & 97 & $1 \mathrm{e}-05$ & 78 \\
RNA 2 & & & & \\
$226-2$ & 225 & 100 & $5 \mathrm{e}-42$ & 95 \\
$381-259$ & 123 & 100 & $1 \mathrm{e}-24$ & 95 \\
$1,112-429$ & 684 & 99 & $5 \mathrm{e}-132$ & 92 \\
$1,273-1,112$ & 162 & 99 & $2 \mathrm{e}-29$ & 98 \\
$1,326-1,664$ & 339 & 100 & $9 \mathrm{e}-71$ & 97 \\
$1,656-1,823$ & 168 & 100 & $1 \mathrm{e}-28$ & 98 \\
$1,812-2,621$ & 810 & 100 & 0 & 99 \\
$2,622-2,732$ & 102 & 97 & $3 \mathrm{e}-16$ & 95 \\
$2,730-3,068$ & 339 & 100 & $1 \mathrm{e}-70$ & 98 \\
$3,141-3,545$ & 405 & 100 & $4 \mathrm{e}-95$ & 99 \\
$3,552-3,848$ & 296 & 100 & $2 \mathrm{e}-61$ & 98 \\
$3,839-4,609$ & 770 & 100 & $3 \mathrm{e}-170$ & 95 \\
$4,638-4,742$ & 105 & 100 & $6 \mathrm{e}-17$ & 100 \\
$4,727-4,671$ & 55 & 100 & $6 \mathrm{e}-04$ & 100 \\
$4,731-5,231$ & 501 & 99 & $2 \mathrm{e}-110$ & 99 \\
$5,406-5,233$ & 174 & 92 & $2 \mathrm{e}-34$ & 95 \\
$5,406-5,636$ & 231 & 100 & $2 \mathrm{e}-42$ & 95 \\
$5,664-5,774$ & 111 & 100 & $3 \mathrm{e}-16$ & 100 \\
$5,892-5,999$ & 108 & 100 & $1 \mathrm{e}-16$ & 97 \\
\hline
\end{tabular}

a Position (contigs that mapped to genomic RNA 1 or RNA 2), coverage, and percent identity to corresponding segments of the reference sequences KF209275 and KF209276.

$\mathrm{b}$ Length in nucleotides (nt)

c Expected value of the Blast match between these contigs and the reference genomic RNAs.
$100 \%$ identical with the reference sequences, and the $e$ values were correspondingly low. The coverage of both genomic RNA molecules was also uniform, with genomic RNA 1 and genomic RNA 2 having 89 and $98 \%$ coverage, respectively, with contigs mapped into all coding regions of the CiLV-C genome. These data verify that, although the RNA quality was poor, the sequence data obtained is reliable and accurate and there is no doubt that this sequence is very similar to the type member of the Cilevirus group. Thus this viral genome, sequenced from Brazil in 2006, was present in Argentina in 1967 and was essentially unchanged since that time.

A second sample of great interest is number 6, originally donated to the herbarium from Florida by Knorr in 1948. In contrast to the reads from the library made to sample 20, which assembled into 106 relatively short contigs, the reads from this library assembled into only 7 long contigs. These contigs mapped directly to CiLV-N isolate M2345 from Mexico (KF209275 and KF209276) (Roy et al. 2013 c), with 91 to $100 \%$ coverage of contigs up to $1,906 \mathrm{nt}$ in length, which led to very low $e$ values (0) when matched to these sequences. However, we note that, although the coverage within contigs was uniform, the sequences themselves were not conserved, with only $80 \%$ identity to reference isolate M2345, and with the variation uniformly present across both RNA1 and RNA2. Also in contrast with the results from CiLV-C number 20 (from Argentina in 1967), the library from CiLV Florida isolate number 6 did not produce contigs that mapped to the entire genome. No matches were found to either the phosphoprotein gene or to the matrix protein genes. Nevertheless, the extensive degree of coverage obtained may be surprising given the small amount of dsRNA produced by negative-sense RNA viruses during replication (Weber et al. 2006), and may have been obtained by products of posttranscriptional gene silencing. However, for genomic RNA 1, note that sequences of the $5^{\prime}$ untranslated region and all of the $N$ and glycoprotein genes were obtained. For genomic RNA 2, 60\% of the sequence was present in three contigs that covered most of the polymerase polyprotein gene, including conserved motifs A, B, and D in domain III (data not shown). It has been known that some form of leprosis virus was previously present in Florida and was very damaging to the industry in the first half of the 20th century (Childers et al. 2003). Others (Kitajima et al. 2011) suggested that the CiLV originally present in Florida was of the nuclear type based on symptoms, though they were not successful at amplification of CiLV sequences from their herbarium specimens.

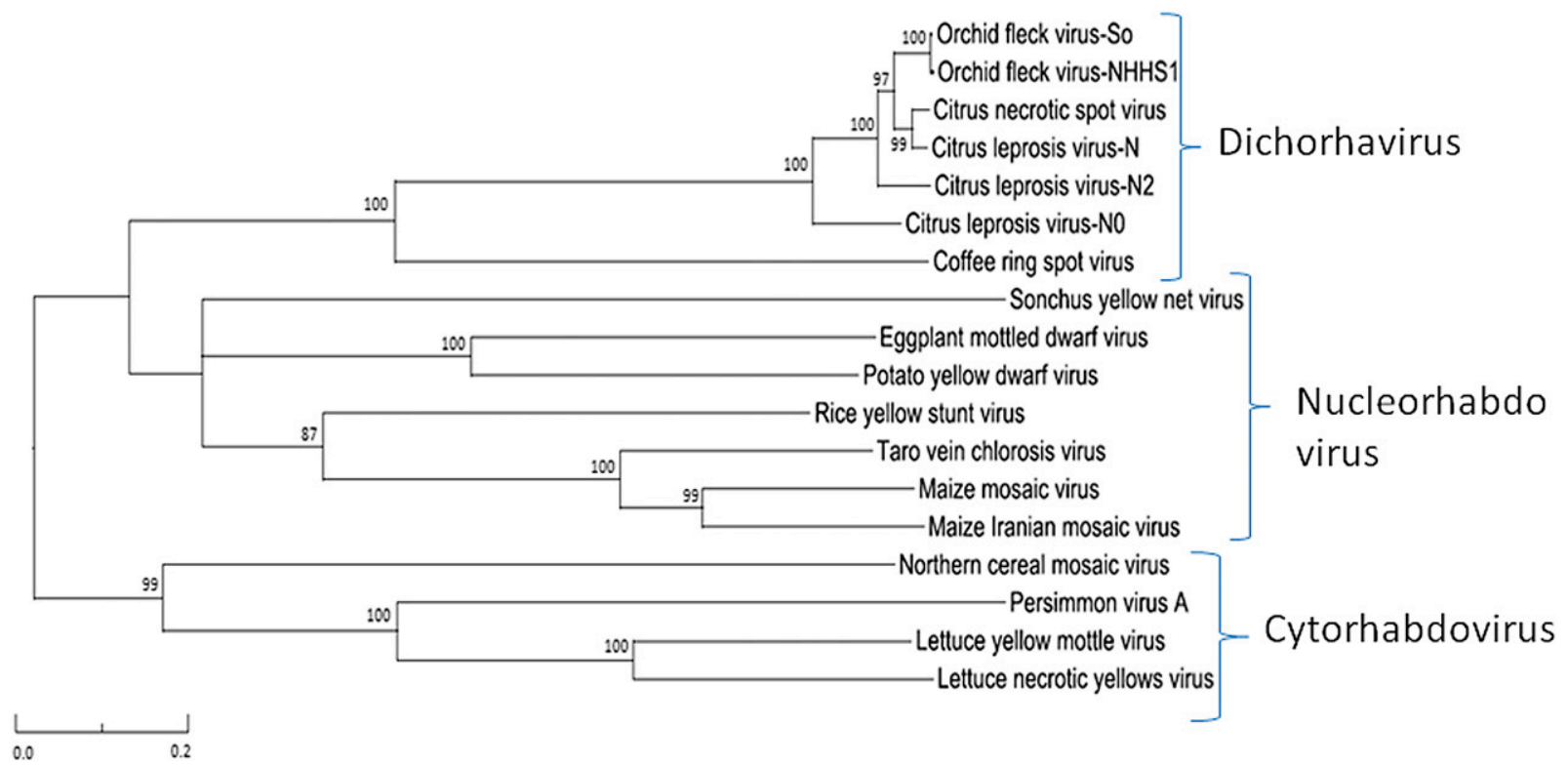

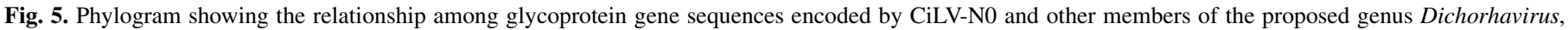
and members of the genera Nucleorhabdovirus and Cytorhabdovirus. The phylogram was calculated with neighbor joining and 10,000 bootstrap replicates. 
This is the first direct demonstration that this was the case, and that the virus was a member of genus Dichorhavirus. Of great interest is that our CiLV-N isolate from Florida, preserved in 1948, is clearly distinct from other members of Dichorhavirus and is most closely related to the CiLV-N2 strains that have recently been characterized in Mexico (Roy et al. 2014). This isolate, which we refer to as CiLV-N0, is not known to exist in the world today although, with the sequence data in hand, we can now begin to search for it. In addition to citrus hosts, it would be useful to test ring spot lesions and flat mites obtained from various ornamental hosts for the presence of this and related viruses (Kitajima et al. 2003).

We also were able to assemble and identify contigs from two samples preserved from Mexico (in 1955 and 1967) that were clearly CiLV-N. The apparent widespread presence of CiLV-N in Mexico in both space and time in the period sampled is a bit surprising, because CiLV-C and CiLV-N were first reported in Mexico in 2005 and 2012 (Anonymous 2005; Cruz-Jaramillo et al. 2014; Izquierdo-Castillo et al. 2011). It may be that CiLV-N was endemic in Mexico but did not cause serious production losses and was not reported. Alternatively, CiLV-N was present in Mexico in the mid-20th century but disappeared, as has been documented to have occurred in Florida. If this is the case, then CiLV-N is a reemerging disease in Mexico, and the sequences present in the herbarium are nearly identical to contemporary strains of CiLV-N from Mexico and not to CiLV-N0, which was deposited in the herbarium in the same era. In either case, our results show that the inspectors at the border stations were correct in their identification of citrus leprosis disease based solely on symptoms on orange fruit entering the United States.

The reads from other sequence libraries did not assemble enough contigs to make clear identification of the virus. The reason these sequence libraries did not provide extensive coverage of the reference genomes by contigs is not known, although sample number 34 from Brazil in 1932 was leaf material rather than fruit peel, and had been oxidized to a black color in storage. The sequence library prepared from this sample was also the smallest in this study, as measured by both total MB and number of reads. In spite of this, we can make a tentative genomic identification of CiLV-C in Brazil in 1932.

In this study, RNA sequencing methodology was used to begin to describe the diversity of viruses associated with citrus leprosis disease preserved in the herbarium. Our recent work using RNA sequencing methodology has revealed that there is a great deal of previously unappreciated diversity within what had formerly been viewed as two viruses. Melzer et al. (2012) have also discovered a novel virus with a tripartite single-stranded and positive-sense RNA genome, which they have named Hibiscus green spot virus. This virus produced symptoms similar to citrus leprosis on C. volkameriana and green ring spot symptoms on Hibiscus arnottianus. Melzer et al. (2013) have also described a Cilevirus sp. on Hibiscus spp. in Hawaii. We have recently described a second type of CiLV-C, CiLV-C2, in Colombia (Roy et al. 2013a), and another novel type of CiLV-N, CiLV-N2, in Mexico (Roy et al. 2014). There is evidence that CiLV-C2, the "new" member of the genus Cilevirus in Colombia, is replacing the previous population of CiLV-C (Roy et al. 2013a; Roy et al. 2015); however, the origin of this new virus, as well as the new members of the genus Dichorhavirus (CiLV-N2) in Mexico, is obscure. There is potential for a pandemic of CiLV-C as this virus but not CiLV-N continues to spread throughout the Americas. This is analogous to the situation with citrus huanglongbing, caused by any of three 'Candidatus Liberibacter spp.' Only one of the three, ' $C a$. Liberibacter asiaticus,' has emerged worldwide (Bové 2006). It is not clear whether CiLV-N is being replaced by CiLV-C as the virus expands its range, or if CiLV-N simply becomes more difficult to find among a larger population of CiLV-C. We now have tools to discover mixed infections of CiLV-C and CiLV-N on sweet orange foliage and fruit, and instances of this have been described (Roy et al. 2015). In light of the related viruses discovered in ornamental plants (Kitajima et al. 2003; Kondo et al. 2006; Melzer et al. 2012, 2013), such plants may also prove to harbor a diverse population of related viruses. It will be interesting to determine whether the increasingly apparent diversity within the populations of the viruses associated with citrus leprosis disease is matched by a diversity in the flat mite vectors, and if relations with and dissemination of the mite vectors drive the spread of both Cilevirus and Dichorhavirus spp. Low-temperature scanning electron microscopy and related new technologies have been used to propose a major revision of the genus Brevipalpus (Geijskes), with significant implications for virus-vector relationships (Beard et al. 2015; Roy et al. 2015). The herbarium specimens described here will allow us to continue to explore the history and evolution of the population of viruses that, together, cause diseases referred to as citrus leprosis across both space and time. A better understanding of the evolution and diversity within this increasingly important group of viruses will contribute to their accurate identification and effective control.The sequence fragments of CiLV-NO have been deposited to GenBank under accession numbers KT187687 to KT187693. The sequence fragments of CiLV-N0 have been deposited to GenBank under accession numbers KT187687 to KT187693.

\section{ACKNOWLEDGMENTS}

We thank A. Rossman and S. Dominick for access to and assistance with the United States National Fungus Collection, C. Paul for preparation of the figures, and D. C. Henderson for assistance with the evaluation of RNA quality.

\section{LITERATURE CITED}

Altschul, S. F., Madden, T. L., Schaffer, A. A., Zhang, J., Zhang, Z., Miller, W., and Lipman, D. J. 1997. Gapped BLAST and PSI-BLAST: A new generation of protein database search programs. Nucleic Acids Res. 25: 3389-3402.

Anonymous. 2005. Sistema de aletra fitosanitaria. Detección de la leprosis en el estado de Chiapas, México. NAPPO North American Plant Protection Organization. Online publication. http://www.pestalert.org/espanol/oprDetail. cfm?oprID=165

Bastianel, M., de Oliveira, A. C., Cristofani, M., Guerreiro Filho, O., Freitas-Astúa, J., Rodrigues, V., Astúa-Monge, G., and Machado, M. A. 2006. Inheritance and heritability of resistance to citrus leprosis. Phytopathology 96:1092-1096.

Bastianel, M., Freitas-Astúa, J., Nicolini, F., Segatti, N., Novelli, V. M., Rodrigues, V., Medina, C. L., and Machado, M. A. 2008. Response of mandarin cultivars and hybrids to Citrus leprosis virus. J. Plant Pathol. 90:307-312.

Bastianel, M., Novelli, V. M., Kitajima, E. W., Kubo, K. S., Bassanezi, R. B., Machado, M. A., and Freitas-Astúa, J. 2010. Citrus leprosis: Centennial of an unusual mite-virus pathosystem. Plant Dis. 94:284-292.

Baulcombe, D. 2004. RNA silencing in plants. Nature 431:356-363.

Beard, J. J., Ochoa, R., Braswell, W. E., and Bauchan, G. R. 2015. Brevipalpus phoenicis (Geijskes) species complex (Acari: Tenuipalpidae)—A closer look. Zootaxa 3944:1-67.

Bitancourt, A. A. 1955. Estudos sobre a leprose dos citros. Arq. Inst. Biol. (Sao Paulo) 22:161-231.

Bové, J. M. 2006. Huanglongbing: A destructive, newly-emerging, century old disease of citrus. J. Plant Pathol. 88:7-37.

Castillo, I. I., Diaz, L. F. Z., Mendez, W., Otero-Colina, G., Freitas-Astúa, J., Locali-Fabris, E. C., Moraes, G. J. d., Calegario, R. F., Tassi, A. D., and Kitajima, E. W. 2011. Confirmation of the presence of the Citrus leprosis virus $C$ (CiLV-C) in Southern Mexico. Trop. Plant Pathol. 36:400-403.

Chagas, C. M., and Rosetti, V. V. 1984. Transmission of leprosis by grafting. In: 9th Conf. Int. Organ. Citrus Virol. University of California, Riverside.

Childers, C. C., Rodrigues, J., Derrick, K., Achor, D., French, J., Welbourn, W., Ochoa, R., and Kitajima, E. W. 2003. Citrus leprosis and its status in Florida and Texas: Past and present. Exp. Appl. Acarol. 30:181-202.

Childers, C. C., Rodrigues, J. C., Kitajima, E. W., Derrick, K. S., Rivera, C., and Welbourn, W. C. 2001. A control strategy for breaking the virus-vector cycle of Brevipalpus spp. and the Rhabdovirus disease citrus leprosis. Manejo Integrado Plagas Costa Rica 60:76-79.

Colariccio, A., Lovisolo, O., Chagas, C. M., Galleti, S. R., Rossetti, V., and Kitajima, E. W. 1995. Mechanical transmission and ultrastructural aspects of citrus leprosis disease. Fitopatol. Bras. 20:208-213. 
Cruz-Jaramillo, J. L., Ruiz-Medrano, R., Rojas-Morales, L., López-Buenfil, J. A., Morales-Galvan, O., Chavarin-Palacio, C., Ramirez-Pool, J. A., and Xoconostle-Cázares, B. 2014. Characterization of a proposed dichorhavirus associated with the citrus leprosis disease and analysis of the host response. Viruses 6:2602-2622.

de Dominguez, F. S., Bernal, A., Childers, C. C., and Kitajima, E. W. 2001. First report of Citrus leprosis virus in Panama. Plant Dis. 85:228.

Dietzgen, R. G., Kuhn, J. H., Clawson, A. N., Freitas-Astúa, J., Goodin, M. M., Kitajima, E. W., Kondo, H., Wetzel, T., and Whitfield, A. E. 2014. Dichorhavirus: A proposed new genus for Brevipalpus mite-transmitted, nuclear, bacilliform, bipartite, negative strand RNA viruses. Arch. Virol. 159:607-619.

Fawcett, H. S. 1911. Scaly bark or nail-head rust of citrus. Fla. Agric. Exp. Stn. Bull. 106:1-41.

Hamilton, A., Voinnet, O., Chappell, L., and Baulcombe, D. 2002. Two classes of short interfering RNA in RNA silencing. EMBO J. 21:4671-4679.

Izquierdo-Castillo, I., Zermeño Diaz, L. F., Mendez, W., Otero-Colina, G., Freitas-Astúa, J., Locali-Fabris, E. C., de Moraes, G. J., Faier Calegario, R., Tassi, A. D., and Kitajima, E. W. 2011. Confirmation of the presence of the Citrus leprosis virus $C$ (CiLV-C) in Southern Mexico. Trop. Plant Pathol. 36:400-403.

Kitajima, E. W., Chagas, C. M., Harakava, R., Calegario, R. F., Freitas-Astúa, J., Rodrigues, J. C. V., and Childers, C. C. 2011. Citrus leprosis in Florida, USA, appears to have been caused by the nuclear type of Citrus leprosis virus (CiLV-N). Virus Rev. Res. 16:23-27.

Kitajima, E. W., Chagas, C. M., and Rodrigues, J. C. V. 2003. BrevipalpusTransmitted plant virus and virus-like diseases: Cytopathology and some recent cases. Exp. Appl. Acarol. 30:135-160.

Kitajima, E. W., Muller, G. W., Costa, A. S., and Yuki, W. 1972. Short, rodlike particles associated with Citrus leprosis. Virology 50:254-258.

Knorr, L. C. 1968. Studies on the etiology of leprosis in citrus. In: Proc. 4th Conf. Int. Organ. Citrus Virol. University of California, Riverside.

Kondo, H., Maeda, T., Shirako, Y., and Tamada, T. 2006. Orchid fleck virus is a rhabdovirus with an unusual bipartite genome. J. Gen. Virol. 87: 2413-2421.

Kondo, H., Maeda, T., and Tamada, T. 2003. Orchid fleck virus: Brevipalpus californicus mite transmission, biological properties and genome structure. Exp. Appl. Acarol. 30:215-223.

Langmead, B., Trapnell, C., Pop, M., and Salzberg, S. L. 2009. Ultrafast and memory-efficient alignment of short DNA sequences to the human genome. Genome Biol. 10:R25.

Li, W., Song, Q., Brlansky, R., and Hartung, J. S. 2007. Genetic diversity of citrus canker pathogens preserved in herbarium specimens. Proc. Natl. Acad. Sci. USA 104:18427-18432.

Locali-Fabris, E. C., Freitas-Astúa, J., Souza, A. A., Takita, M. A., Astua-Monge, G., Antonioli-Luizon, R., Rodrigues, V., Targon, M. L. P. N., and Machado, M. A. 2006. Complete nucleotide sequence, genomic organization and phylogenetic analysis of Citrus leprosis virus cytoplasmic type. J. Gen. Virol. 87:2721-2729.

Loconsole, G., Onelge, N., Potere, O., Giampetruzzi, A., Bozan, O., Satar, S., De Stradis, A., Savino, V., Yokomi, R. K., and Saponari, M. 2012a. Identification and characterization of citrus yellow vein clearing virus, a putative new member of the genus Mandarivirus. Phytopathology 102: 1168-1175.

Loconsole, G., Saldarelli, P., Doddapaneni, H., Savino, V., Martelli, G. P., and Saponari, M. 2012b. Identification of a single-stranded DNA virus associated with citrus chlorotic dwarf disease, a new member in the family Geminiviridae. Virology 432:162-172.

Melzer, M. J., Sether, D. M., Borth, W. B., and Hu, J. S. 2012. Characterization of a virus infecting Citrus volkameriana with citrus leprosis-like symptoms. Phytopathology 102:122-127.

Melzer, M. J., Simbajon, N., Carillo, J., Borth, W. B., Freitas-Astúa, J., Kitajima, E. W., Neupane, K. R., and Hu, J. S. 2013. A cilevirus infects ornamental hibiscus in Hawaii. Arch. Virol. 158:2421-2424.

Nicholas, K. B., and Nicholas, H. B., Jr. 1997. GeneDoc: A tool for editing and annotating multiple sequence alignments. distributed by the author, 14 .

Pascon, R. C., Kitajima, J. P., Breton, M. C., Assumpcao, L., Greggio, C., Zanca, A. S., Okura, V. K., Alegria, M. C., Camargo, M. E., Silva, G. G., Cardozo, J. C., Vallim, M. A., Franco, S. F., Silva, V. H., Jordao, H., Jr., Oliveira, F., Giachetto, P. F., Ferrari, F., Aguilar-Vildoso, C. I., Franchiscini,
F. J. B., Silva, J. M. F., Arruda, P., Ferro, J. A., Reinach, F. and da Silva, A. C. R. 2006. The complete nucleotide sequence and genomic organization of citrus leprosis associated virus, cytoplasmatic type (CiLV-C). Virus Genes 32:289-298.

Ristaino, J. B. 1998. The importance of archival and herbarium materials in understanding the role of oospores in late blight epidemics of the past. Phytopathology 88:1120-1130.

Ristaino, J. B., Groves, C. T., and Parra, G. R. 2001. PCR amplification of the Irish potato famine pathogen from historic specimens. Nature 411:695-697.

Rodrigues, J. C. V., Kitajima, E. W., Childers, C. C., and Chagas, C. M. 2003. Citrus leprosis virus vectored by Brevipalpus phoenicis (Acari: Tenuipalpidae) on citrus in Brazil. Exp. Appl. Acarol. 30:161-179.

Rodrigues, J. C. V., Zuniga Reyes, J. A., Achor, D. S., Childers, C. C., and Kitajima, E. W. 2006. Occurrence and distribution of Citrus leprosis virus in Honduras. New Dis. Rep. 13:37.

Roy, A., Choudhary, N., Guillermo, L. M., Shao, J., Govindarajulu, A., Achor, D., Wei, G., Picton, D. D., Levy, L., Nakhla, M., Hartung, J. S., and Brlansky, R. H. 2013a. A novel virus of the genus Cilevirus causing symptoms similar to Citrus leprosis. Phytopathology 103:488-500.

Roy, A., Hartung, J. S., Schneider, W. L., Shao, J., Leon, G., Melzer, M. J., Beard, J. J., Otero-Colina, G., Bauchan, G. R., Ochoa, R., and Brlansky, R. H. 2015. Role bending: Complex relationships between viruses, hosts, and vectors related to citrus leprosis, an emerging disease. Phytopathology 105:1013-1025

Roy, A., Shao, J., Hartung, J. S., Schneider, W., and Brlansky, R. H. 2013b. A case study on discovery of novel Citrus leprosis virus cytoplasmic type 2 utilizing small RNA libraries by next generation sequencing and bioinformatic analyses. J. Data Min. Genomics Proteomics 4:1000129.

Roy, A., Stone, A., Otero-Colina, G., Schneider, W. L., Hartung, J. S., and Brlansky, R. H. 2014. Genetic variability in the nucleocapsid genes of nuclear Citrus leprosis virus reveals the presence of a distinct species of dichorhavirus. Phytopathology 104:S3.101.

Roy, A., Stone, A., Otero-Colina, G., Wei, G., Choudhary, N., Achor, D., Shao, J., Levy, L., Nakhla, M. K., Hollingsworth, C. R., Hartung, J. S., Schneider, W. L. and Brlansky, R. H. 2013c. Genome assembly of Citrus leprosis virus nuclear type reveals a close association with Orchid fleck virus. Genome Announc. 1:e00519-13.

Schroeder, A., Mueller, O., Stocker, S., Salowsky, R., Leiber, M., Gassmann, M., Lightfoot, S., Menzel, W., Granzow, M., and Ragg, T. 2006. The RIN: An RNA integrity number for assigning integrity values to RNA measurements. BMC Mol. Biol. 7:3.

Schulz, M., Zerbino, D., Vingron, M., and Birney, E. 2012. Oases: Robust de novo RNA-seq assembly across the dynamic range of expression levels. Bioinformatics 28:1086-1092.

Stall, R. E., and Civerolo, E. L. 1993. Xanthomonas campestris pv. citri: Cause of citrus canker. Pages 48-51 in: Xanthomonas. J. G. Swings and E. L. Civerolo, eds. Chapman and Hall, New York.

Tamura, K., Stecher, G., Peterson, D., Filipski, A., and Kumar, S. 2013. MEGA6: Molecular evolutionary genetics analysis version 6.0. Mol. Biol. Evol. 30:2725-2729.

Thompson, J. D., Gibson, T. J., Plewniak, F., Jeanmougin, F., and Higgins, D. G. 1997. The Clustal X Windows interface: Flexible strategies for multiple sequence alignment aided by quality analysis tools. Nucleic Acids Res. 25:4876-4882.

Weber, F., Wagner, V., Rasmussen, S. B., Hartmann, R., and Paludan, S. R. 2006. Double-stranded RNA is produced by positive-strand RNA viruses and DNA viruses but not in detectable amounts by negative-strand RNA viruses. J. Virol. 80:5059-5064.

Xu, Q., Chen, L.-L., Ruan, X., Chen, D., Zhu, A., Chen, C., Bertrand, D., Jiao, W.-B., Hao, B.-H., Lyon, M. P., Chen, J., Gao, S., Xing, F., Lan, H., Chang, J.-W., Ge, X., Lei, Y., Hu, Q., Miao, Y., Wang, L., Xiao, S., Biswas, M. K., Zeng, W., Guo, F., Cao, H., Yang, X., Xu, X.-W., Cheng, Y.-J., Xu, J., Liu, J.-H., Luo, O. J., Tang, Z., Guo, W.-W., Kuang, H., Zhang, H.-Y., Roose, M. L., Nagarajan, N., Deng, X.-X., and Ruan, Y. 2012. The draft genome of sweet orange (Citrus sinensis). Nat. Genet. 45:59-66.

Yoshida, K., Burbano, H. A., Krause, J., Thines, M., Weigel, D., and Kamoun, S. 2014. Mining Herbaria for Plant Pathogen Genomes: Back to the Future. PLoS Pathog. 10:e1004028.

Zerbino, D., and Birney, E. 2008. Velvet: Algorithms for de novo short read assembly using de Bruijn graphs. Bioinformatics 18:821-829. 